\title{
Boko Haram, al-Qaeda in the Islamic Maghreb, al-Shabaab - Similarities and Differences
}

\section{An Analysis of the Genesis, Evolution and Strategies of the Islamist Violent Extremist Groups in Africa ${ }^{1}$}

The authors offer an analysis of the genesis, evolution, and strategies of three Islamist extremist groups in three parts of Africa: al-Qaeda in the Islamic Maghreb (AQIM) in the borderland of Algeria and Mali; Boko Haram in the borderland of Nigeria, Chad, Niger and Cameroon; and al-Shabaab in Eastern Africa. Through examining the three comparative case studies they argue that the religious agenda of these groups plays the role of a façade only. The most important reasons of the spread of terrorism in all three regions are related to the political and economic conditions, feelings of relative deprivation, low level of trust in government authorities and the frustration of marginalised groups.

Keywords: Boko Haram, al-Qaeda, al-Shabaab, Maghreb, terrorism, extremism, Africa

\section{Introduction}

Five years after the tragic events of 9/11, the retribution machinery of the so called "War on Terror" against the global Islamist insurgency was running at full speed. With ongoing military interventions in Afghanistan, Iraq and drone strikes or special forces operations in Pakistan, Yemen, Somalia, the invisible fronts of the conflict were being pushed far away from American and European soil. That time, on the fifth anniversary of the terrorist ${ }^{2}$ attacks on the Twin Towers and the Pentagon, Ayman az-Zawahiri, a senior member of al-Qaeda, officially recognised the Algerian Salafist Group for Preaching and CombatGroupe Salafiste pour la Prédication et le Combat, GSPC) as the al-Qaeda affiliate on the Sahara, declaring the birth of their "blessed union".

This work was created in commission of the National University of Public Service under the priority project PADOP2.1.2-CCHOP-15-2016-00001 entitled "Public Service Development Establishing Good Governance" in the Ludovika Research Group.

2 Throughout this article, due to the lack of compromise on the definition, terrorism will be understood as any wilful targeting of non-combatants with violence or the threat of violence for political purposes by a non-state actor. Consequently, those committing such deeds will be referred to as terrorists. (DAviEs, John: Understanding Terrorism in Africa. In: DAvies, John [ed.]: Terrorism in Africa. The Evolving Front in the War on Terror. Lexington Books, Lanham, 2010, pp. 133-158.)

Pнам, J. Peter: Foreign Influences and Shifting Horizons: The Ongoing Evolution of al Qaeda in the Islamic Maghreb. Orbis, Vol. 55, No. 2, 2011, p. 240. 
Thus, al-Qaeda in the Islamic Maghreb (AQIM) - a terrorist organisation infamous for its numerous kidnappings for million-dollar bounties, ${ }^{4}$ filmed executions of Western nationals, and even an attempt to create an Islamist emirate in the Sahara - has been established. The creation of AQIM, or - to be more precise - the incorporation of the Algerian extremist group into the global network of al-Qaeda, although symbolic, did not mark the birth of the radical and violent Islamism on the African continent. Its roots, far too frequently, can be traced back to the Somali Jihad against Ethiopia in the $15^{\text {th }}$ century, the Jihad of Usman dan Fodio (1804-1808), or to the spread of the Salafi movement (19 ${ }^{\text {th }}$ century).

\section{The spread of Salafism in the Maghreb}

Salafism (as-Salafiya - the road of forefathers) is a fundamentalist ${ }^{5}$ ideology and movement that embraces a "pure" and exclusive form of Islam in all aspects of life, rejects modern "moral corruption", oppose Western ideologies, and associates the West with decadency. The concept is known since at least the $14^{\text {th }}$ century and it has its Saudi branch called Wahhabism since the $18^{\text {th }}$ century. On the African continent, it gained ground in the $19^{\text {th }}$ century Egypt in opposition to the conquest of Napoleon Bonaparte (1798), and the moral and civilizational decline that the French occupation was believed to have brought to the Egyptians. Salafism inspired Hassan al-Banna, the founder of the Muslim Brotherhood.

At the beginning of the $20^{\text {th }}$ century, Salafi ideology appeared in Algeria and manifested itselfin the formation of the Algerian Association of Muslim Ulema (Association des Oulémas Musulmans Algériens, AUMA) in 1931 - an organisation that rejected Maraboutism (local African beliefs incorporated into Islam), Secularism, Socialism, and even the Islamic Sufi brotherhoods, and opted for Islamic Algeria. Thus, Algerian Islamism formed, though it remained in the shadows of secular independence movements (the governing National Liberation Front, Front de Libération Nationale, FLN) until the early 1980 s. $^{6}$

The history of the politicisation of the Algerian Islamists is highly representative for the analysis of the genesis, evolution and strategies of the violent extremist groups in Africa. Two decades after the independence (1962), the condition of the Algerian state was vulnerable. Throughout the 1980s, the support towards the secular one-party government and military rule that dominated the Algerian politics since the independence, significantly decreased, mostly due to economic hardships and the emergence of the educated but unemployed and marginalised youth. In the early 1980s, the Armed Islamic Movement (Mouvement Islamique Armé, MIA) was formed as an armed opposition to the government of the FLN. The popular unrest culminated in riots of hittistes (young unemployed urban

The kidnapping income of AQIM between 2008 and 2012 was estimated at 40-65 million USD. See LACHER, Wolfram: Organized Crime and Conflict in the Sahel-Sahara Region. Carnegie Endowment for International Peace, Washington, 2012, p. 9.

5 For the purpose of this article fundamentalism is understood, as explained by Malise Ruthven, as "a 'religious way of being' that manifests itself in a strategy by which beleaguered believers attempt to preserve their distinctive identity as a people or group in the face of modernity and secularization." Ruthven, Malise: Fundamentalism. The Search for Meaning. Oxford University Press, New York, 2004, p. 8.

6 Kepel, Gilles: Jihad: The Trail of Political Islam. Belknap Press, New York, 2002, p. 55. 
males) on the streets of Algiers in 1988 that led to reforms and the opening of the political scene. Multiparty elections were held and an offshoot of the Muslim Brotherhood, the Islamic Salvation Front (Front Islamique du Salut, FIS) won the majority in the first round of parliamentary elections. The first Islamic party on the Algerian political scene secured vast support of the devout middle class, and especially of the politically and economically marginalised and jobless youth. ${ }^{7}$

Simultaneously, Algerian veterans of the Afghan war against the Soviet Union returned home. They brought with them the radical ideology, military experience and - most importantly - the faith that with jihad they can challenge the 'infidel' secular regime and win over one of the most powerful armies in the world. ${ }^{8}$ This external experience was soon to be exploited in their own homeland. Thus jihad - in its violent and distorted meaning $^{9}$ - became a globalised phenomenon.

Since the very beginning of its formation, FIS has not concealed its goals to introduce sharia law, abolish future elections and create an Islamic state. In the wake of gaining two thirds of the parliamentary seats by FIS, that would allow to change the constitution and democratically introduce the Islamic rule, the acting political elites and the army decided to invalidate the election results and ban FIS. Protests erupted, martial law was introduced, and the military organised a coup détat in January 1992. The most radical Islamists called to retake power by resorting to violence and the first attack on a military post took place at the end of 1991. A violent Jihad, led by fundamentalist groups against the secular government, was initiated. The following Algerian "dirty war" (la sale guerre) lasted a decade and claimed up to two hundred thousand lives, mostly civilians.

The religious component in the Algerian civil war was highly significant as a tool that consolidated the anti-government movements and provided them with a single and coherent identity - in fact Islam had already served as an identity marker in the time of the Algerian independence war. Yet as Amartya Sen noted, "identity can also kill - and kill with abandon. [...] Violence is fomented by the imposition of singular and belligerent identities on gullible people, championed by proficient artisans of terror" ${ }^{10}$ Although religion was consolidating the anti-governmental movements, the establishment of a religion-based political system seemed to have never been the agenda of the majority of the Algerian population. The societal basis of FIS consisted of the devout (yet not radical) middle-class and the disillusioned youth that faced economic hardships, lack of prospects, and experienced so-called "relative deprivation" (being well educated but lacking the proper employment). It appears that they considered the competing Islamic political system the solution to their

Harmon, Stephen A.: Terror and Insurgency in the Sahara-Sahel Region: Corruption, Contraband, Jihad and the Mali War of 2012-2013. Ashgate, Burlington-Farnham, 2014, pp. 48-49.

8 Filiu, Jean-Pierre: The Local and Global Jihad of al-Qa'ida in the Islamic Maghreb. Middle East Journal, Vol. 63, No. 2, 2009, pp. 213-226.

9 The meaning of Jihad, as promoted by the radicals, "the aggressive and violent holy war against the (broadly defined) infidels" has not much to do with the accepted religious meaning of the term which stands for internal and spiritual struggle with one's own weaknesses (according to a popular hadith, the prophet Muhammad called this the greater Jihad) and fight against the polytheists (historical meaning) or self-defence of the Muslim community (considered the lesser Jihad). AL-Ashmawy, Muhammad Said: Islam and the Political Order. The Council for Research in Values and Philosophy, Washington, D.C., 1994, pp. 69-76.

10 Sen, Amartya: Identity and Violence: The Illusion of Destiny. Norton and Company, New York, 2006, pp. 1-2. 
economic and social problems rather than the end-goal. Consequently, the authors claim and intend to validate this in the following paragraphs by showing that motivations of various Islamist groups' members transcend the religious agenda which is rather a façade, founded on social and economic deprivations and political disillusionment. Similarly, the ultimate goals of all further discussed terrorist organisations are solely political, not religious, as they never strive to spread whichever God's word, yet rather seek to overthrow the existing political system and replace it with another.

\section{GIA, GSPC and the emergence of al-Qaeda in the Islamic Maghreb}

Initially, some moderate leaders of FIS called for restoring the democratic order and repeating the elections, yet it soon turned out that the leadership of the party is unable to control its diverse electorate (specifically the youth and unemployed so susceptible to radicalisation). Radical Islamists separated from the core of FIS and created the Islamic Armed Group (Groupe Islamique Armé, GIA) to fight with the government. They unilaterally declared FIS and anyone else 'apostates'. Mourad si Ahmed, known as Djafar el-Afghani, as he fought in Afghanistan, soon became its emir. The brutal campaign of terror took off in Algeria: GIA targeted not only the government, but also other Islamists and civilians (declaring "the apostasy of society" for failing to support the group), and in 1995 organised a campaign of terror in France. For conducting brutal and indiscriminate attacks against the Algerian civilian population and other Islamists, the group was highly criticised by foreign fundamentalist movements. In 1998 a regional leader, Hassan Hattab quit the organisation and established the Salafist Group for Preaching and Combat (Groupe Salafiste pour la Prédication et le Combat, GSPC). In 1999, the ranks of the newly formed group were joined by the Islamists who rejected the peace accord with the government and at the same time opposed the brutal campaign of terror led by GIA. The organisation rose to prominence. In consequence, at the turn of the $21^{\text {st }}$ century, when the Algerian civil war was drawing to an end, only the most radical adepts of "the nihilistic jihad" remained in the battlefield, ready to "drown the Umma ${ }^{11}$ in blood in order to save it" - as Alfred de Montesquiou put it. ${ }^{12}$

The initial 'base' of GSPC extended to the territories in North-Eastern Algeria, later though, the organisation expanded their operations southwards to the Sahara, entering Northern Mali, Eastern Mauritania, Western Niger and North-Western Chad. The territorial expansion was followed by broadening the illicit activity of the group. During the 1990s, all armed Islamist groups were financed by common banditry, extortions, robberies and taxing trans-Saharan smuggling and trafficking (al-Frud) of both legal (Frud al-Halal) and illicit goods (Frud al-Haram). Since 2003, though, GSPC engaged into kidnapping of Western nationals - a business that proved to be worth millions of dollars. Kidnapping 32 tourists in the first half of 2003 brought the media attention what might have helped adver-

\footnotetext{
Umma is the global community of all Muslims.

12 Harmon (2014): op. cit. 52-55; De Monetsquiou, Alfred: Umma. Reporter na Bliskim Wschodzie. Terra Incognita, Warszawa, 2015, p. 96. [Original title: Oumma: un grand reporter au Moyent-Orient. Seuil, Paris, 2013.]; PHAM (2011): op. cit. 242-243; Schanzer, Jonathan: Al-Qaeda's Armies: Middle East Affiliate Groups and the Next Generation of Terror. Washington Institute for Near East Policy, Washington, D.C., 2004, p. 106.
} 
tise the group to the al-Qaeda core. For GSPC, joining the global network of Jihad under the al-Qaeda brand boasted legitimacy, thus increasing recruitment; for the al-Qaeda core, it helped increasing its global prestige and outreach. ${ }^{13}$

The Algerian Government crackdown on GSPC and the group's increased contacts with al-Qaeda influenced its organisation and tactics. The estimated overall manpower of the group fell from ca. 4,000 in 2002 to not more than 500 in 2006. In such circumstances the Saharan affiliate switched to al-Qaeda's 'weapon of choice', like relying on improvised explosive devices (IED) and suicide bombings, known to be effective from Afghanistan and Iraq. It seemed much more suitable in their situation than the insurgency-like irregular warfare employed previously in the Algerian conflict, especially by GIA. In 2005, under the leadership of Abdelmalek Droukdel (a.k.a. Musab Abdelwadud), the GSPC was still capable of organising several important attacks on targets in Algeria and one on the Lemgheiti military base in Eastern Mauritania, killing there 15 soldiers, and mobilised around 100-150 GSPC fighters. Although the Algerian counterterrorist operations put pressure on the Saharan al-Qaeda affiliate and forced the group to scale down its attacks on governmental and military targets, it seems highly possible that it also pushed the group to change the tactic - since 2008 it has been observed that AQIM increasingly engaged in kidnappings of Western nationals. Obviously, this activity did not entail as much retribution as killing members of the military or public officials and brought much more income. ${ }^{14}$

By 2012, the AQIM operational territory encompassed Southern Algeria and Northern Mali (where the group found its safe haven in Kidal province after repetitive Algerian crackdowns), ${ }^{15}$ but its activities were conducted also in the neighbouring states of Mauritania and Niger, and possibly but surely much rarely in Burkina Faso, Nigeria, Chad and Libya. ${ }^{16}$ Its main income is based on trafficking and taxing the smuggling of licit (e.g. cigarettes) and illicit goods (inter alia arms, cocaine, marihuana) or people via Saharan routes, and kidnappings. Yet the Tuareg rebellion, that AQIM joined in January 2012, gave the group another possibility to manifest its power and to establish an Islamic political entity in the Sahara. Together with other Islamist groups operating in Northern Mali (like Ansar Dine and Movement for Oneness and Jihad in West Africa, Mouvement pour l'Unité et le Jihad en Afrique de l'Ouest, MUJAO), the extremists overrun and marginalised the secular Tuareg movement within the insurgency and established their sharia-guided rule in the Northern provinces of Mali (Gao, Timbuktu, and Kidal). The territory, similar in size to Western Europe, was run by criminal and terrorist actors for more than half a year until the French intervention, "Operation Serval", in the beginning of 2013 pushed them out and scattered them in the desert. It showed that violent extremist groups, such as GIA/GSPC/AQIM

13 Harmon (2014): op. cit. 13, 52-55; LaUb, Zachary - Masters, Jonathan: Al-Qaeda in the Islamic Maghreb (AQIM), [online], 2015. Source: Council on Foreign Relations [31.08.2017.]

14 Pham (2011): op. cit. 244; Fowler, Robert: A Season in Hell. My 130 Days in the Sahara with Al Qaeda. Harper Collins, New York, 2011.

15 McGovern, Mike: Islamist Terrorism in the Sahel: Fact or Fiction?, [online], 2005. Source: International Crisis Group, Africa Report 92.1 [13.09.2017.]; PrIngle, Robert: Democratization in Mali: Putting History to Work. U.S. Institute of Peace, Washington, 2006, p. 33.

16 Recently Southern Libya tends to be a terrorist safe haven in the Sahara as the country is torn by civil war, and it is outside the scope of French military counterterrorist operations codenamed "Barkhane", conducted in five Saharan states: Mauritania, Mali, Niger, Chad and Burkina Faso. 
were capable of conducting an insurgency campaign in Algeria in the 1990s, taxing or trafficking arms, goods and people throughout the whole Sahara, kidnapping Western nationals for million-dollar ransoms. Islamist terrorist groups operating in the Sahara proved to be highly efficient, flexible and adaptive to the circumstances. Thus their 'hybrid' potential cannot be underestimated and even though the rule of law has been restored in the cities of Northern Mali, the extremists remained hidden in the desert and are capable of conducting disruptive terrorist attacks against the United Nations' peacekeepers, national authorities and the civilian population in the Saharan states.

\section{Boko Haram in Nigeria}

During the Malian crisis, the linkage between different terrorist groups became clearly visible. Lots of commentators admitted that MUJAO, AQIM, Ansar Dine might have cooperated with the Nigerian organisation, Boko Haram. Boko Haram was founded by a charismatic Muslim cleric Mohammed Yusuf in 2002 in Maiduguri, the capital of the state of Borno. Presently the leader of the movement is Abubakar Shekau. The group's official name was Group of the People of Sunnah for Preaching and Jihad. ${ }^{17}$ Boko Haram was designated a terrorist group by the U.S. in 2013. The organisation had alleged links to al-Qaeda in the Islamic Maghreb. In 2015, Boko Haram announced its allegiance to the Islamic State of Iraq and the Levant (Daesh). ${ }^{18}$ Thus, the group's official name was changed to "Islamic State in West Africa."

At the beginning, Boko Haram was a radical but predominantly non-violent sect. People were attracted by the religious ideology and - what is also important to underline - by the micro-lending model (Mohammed Yusuf was able to offer people small amounts of money which they used to set up small businesses). ${ }^{19}$ The start-up of Boko Haram resembles the beginnings of many other non-governmental institutions formed in Nigeria after the death of the military dictator, General Sani Abacha in 1998, and the prelude of the democratisation process in the Fourth Nigerian Republic.

After the clashes between Boko Haram and the Nigeria Police Force and Yusuf's death in 2009, the organisation went underground and radicalised its ideology. The group initially focused on withstanding secular education ("boko haram" in the Hausa and Arabic language means "the Western education is forbidden and sinful" ${ }^{20}$ and - more broadly - on opposing the Westernisation of Nigeria and the presence of Europeans and Americans in Africa. Its main religious and political goals were to implement the rule of "true" Sharia law and create a separate Islamic state, consisting of the Northern states of

\footnotetext{
Murtada, Ahmad: "Boko Haram" in Nigeria: Its Beginnings, Principles and Actions in Nigeria. Bayero University, Kano, 2013, pp. 3-4.

18 YAHAYA, Abubakar: Boko Haram and Islamic State of Iraq and Syria: The Nexus. Polac International Journal of Humanities and Security Studies, Vol. 2, No. 1, 2016, pp. 299-312.

19 Boko Haram: An Assessment of Strengths, Vulnerabilities, and Policy Options Report to the Strategic Multilayer Assessment Office, Department of Defense, and the Office of University Programs, Department of Homeland Security, [online], 2015, College Park: National Consortium for the Study of Terrorism and Responses to Terrorism - University of Maryland. Source: UMD.edu [22.08.2017.]

20 Moland, Naomi A.: Can Multiculturalism Be Exported? Dilemmas of Diversity on Nigeria's Sesame Square. Comparative Education Review, Vol. 59, No. 1, 2015, p. 10.
} 
Nigeria, where the majority of Nigerian Muslims are concentrated in, and - what should be highlighted - where Sharia has been formally instituted (for example: Zamfara, Kano, Sokoto, Katsina, Bauchi, Borno, Jigawa, Kebbi, Yobe). Boko Haram also delegitimises the Nigerian state and Islamic leaders who cooperate with the government. The group criticises corruption in Nigeria, the underdevelopment of the Northern states, the concentration of the wealth of the country among members of the political elite, mainly in the Christian South of Nigeria, the grievances over the distribution of federal resources, and the failure of Northern political and religious elites to sufficiently defend Muslim interests. ${ }^{21}$

Boko Haram camps are situated in the Mandara Mountains, close to the border with Cameroon, and the Sambisa Forest, in the marshes between the states of Borno, Yobe, Gombe and Adamawa. Boko Haram is frequently perceived as a kind of Salafi-inspired sect, and Mosques are seen only as places where new recruits can be approached. It is true that the multi-ethnic - but mostly Kanuri-dominated - group attracted followers from unemployed, uneducated, bigoted, young peasants (mostly men) from the states mentioned above. Therefore, it should be emphasised, that the complex of these four factors - young age, poverty, the lack of education and work, religious beliefs - are the main reasons for joining Boko Haram. ${ }^{22}$ The total strength of Boko Haram is not clear; it is estimated to control up to 3,000-5,000 people.

The group gets funding from bank robberies, ransoms, human trafficking, donations from Islamist sympathisers and presumably drug trafficking. The group is clearly expanding its activities from raids on motorbikes to killing police officers, politicians, attacks on police stations and other government installations, but also to bombing churches, burning schools, killing teachers and kidnapping children. (For instance, on the night of 14-15 April 2014, 276 female students were kidnapped from a school in the town of Chibok). The strategy of Boko Haram progressively shifted towards mass violence - temporary capture of villages and towns (inhabited by Muslims) and armed struggle with the federal troops. ${ }^{23}$ Since the last decade, Boko Haram has killed approximately 20,000 and displaced more than 2 million from their homes. In 2018, Boko Haram presented a very different profile from just a few years earlier. The organisation, once perceived as exclusively "Nigerian", has expanded its presence from the Northern part of the country to the Lake Chad Basin (Cameroon, Niger, Nigeria and Chad). ${ }^{24}$

\section{Al-Shabaab in Somalia}

Al-Shabaab is a Salafist-Jihadist fundamentalist, clan-based insurgent group based in the Horn of Africa, also active in Kenya, Ethiopia, Djibouti, Uganda and Tanzania. It is

21 Kendhammer, Brandon: The Sharia Controversy in Northern Nigeria and the Politics of Islamic Law in New and Uncertain Democracies. Comparative Politics, Vol. 45, No. 3, 2013, p. 296 and 306.

22 Uzodike, Ufo Okeke - Mainngwa, Benjamin: Boko Haram Terrorism in Nigeria: Casual Factors and Central Problematic. Africa Renaissance, Vol. 9, No. 1, 2012, pp. 91-118.

23 Thomas, Jakana: Rewarding Bad Behavior: How Governments Respond to Terrorism in Civil War. American Journal of Political Science, Vol. 58, No. 4, 2014, pp. 808-809.

24 Angerbrandt, Henrik: Nigeria and the Lake Chad Region Beyond Boko Haram. Policy Note - the Nordic Africa Institute, No. 3, 2017, p. 3 and 7. 
a successor organisation to the Islamic Courts Union, which controlled most of Southern Somalia in 2006. ${ }^{25}$ The first "emirs" of al-Shabaab were Aden Hashi Ayro and Ahmed Abdi Godane. Following the death of Ahmed Abdi Godane in 2014, the leader of the organisation became Abu Ubaydah (also known as Ahmed Diriye). The group's official name is the "Movement of Striving Youth". ${ }^{26}$

Al-Shabaab was designated a terrorist group by the U.S. in 2008. Originally an indigenous, independent group, it gradually moved into the al-Qaeda orbit and announced its allegiance to al-Qaeda in 2009. In 2015, a secessionist al-Shabaab commander, Abdul Qadir Mumin and some of his followers pledged allegiance to the Islamic State of Iraq and the Levant, but most members of al-Shabaab remained loyal to al-Qaeda. ${ }^{27}$

Al-Shabaab's main religious and political goals were to support global Jihad, and - on the "national" level - to establish a society based on its rigid interpretation of Sharī'ah law, to create a separate Islamic state incorporating all parts of "Greater Somalia" - the land where ethnic Somalis have historically ever lived (Somalia, Eastern Djibouti, Eastern Kenya, Ogaden and the Haud in Ethiopia). ${ }^{28}$

Al-Shabaab controls parts of Somalia's Southern and Central regions. The composition of the organisation is multi-ethnic, with its leadership positions mainly occupied by Somalis, some of whom were trained in Afghanistan. The core of the organisation consists of veterans of the Somali civil war. Al-Shabaab has also set up a recruiting network in Uganda, Ethiopia, Djibouti, Kenya and Tanzania. Its propaganda videos appear to show entire East African, Swahili-speaking units training and fighting together inside Somalia. Now the group is hoping to mobilise the Somali Muslim Diaspora in the United States, Canada and in Scandinavia. ${ }^{29}$ The total size of Al-Shabaab is not clear, it is estimated to have 5,000-10,000 fighters.

The group received funds and training from al-Qaeda-linked foreign Jihadists. Al-Shabaab also obtained funds from the Somali diaspora communities. ${ }^{30}$ Before 2012, al-Shabaab militants controlled Kismayo, an important port city from which they received massive profits in trading charcoal, ivory and sugar exports. ${ }^{31}$ It is worth to add that the organisation derives much of its predatory income from the movement of the Asian heroin and locally produced qat. ${ }^{32}$

25 Cliffe, Lionel - Love, Roy - Tronvoll, Kjetil: Conflict and Peace in the Horn of Africa. Review of African Political Economy, Vol. 36, No. 120, 2009, pp. 155-156.

26 Chesney, Robert M.: Beyond the Battlefield, Beyond Al Qaeda: The Destabilizing Legal Architecture of Counterterrorism. Michigan Law Review, Vol. 112, No. 2, 2013, p. 165.

27 Al-Shabaab as a Transnational Security Threat. IGAD Security Sector Program (ISSP) and Sahan Foundation, Addis Ababa, 2016, pp. 11-12.

28 Coleman, Katharina P.: Innovations in 'African solutions to African problems': the evolving practice of regional peacekeeping in sub-Saharan Africa. Journal of Modern African Studies, Vol. 49, No. 4, 2011, p. 530.

29 KLeIn, Adam: The End of Al Qaeda? Rethinking the Legal End of the War on Terror. Columbia Law Review, Vol. 110, No. 7, 2010, pp. 1885-1886.

30 Cronin, Audrey K.: The evolution of counter-terrorism: will tactics trump strategy? International Affairs, Vol. 86, No. 4, 2010, p. 849.

31 Little, Peter D.: On the Somalia Dilemma: Adding Layers of Complexity to an Already Complex Emergency. African Studies Review, Vol. 55, No. 1, 2012, p. 192.

32 Qat is an Arabian shrub (Catha edulis), whose leaves are chewed (or drunk as an infusion) as a stimulant. 
Al-Shabaab has claimed responsibility for many bombings, typically targeting Somali government officials, journalists, the African Union Mission in Somalia (AMISOM), and perceived allies of the Federal Government of Somalia. ${ }^{33}$ Al-Shabaab used guerrilla and terror tactics against AMISOM troops - perceived as the Christian crusaders, who wanted to defame Islam and its followers. Recent moves by al-Shabaab indicate not only the rejection of foreign interference in the Somali civil war, but also a willingness to export that war to Somalis outside of Somalia - to make it a civil war, not within Somalia, but among Somalis. ${ }^{34}$ Since 2010 al-Shabaab has launched high-profile operations in neighbouring countries: suicide bombings carried out against crowds watching a screening of the 2010 FIFA World Cup Final in Kampala (Uganda); the Westgate shopping centre attack in Nairobi in 2013 (Kenya); attack against a restaurant in Djibouti, popular with Westerners in 2014; the massacre of university students in Garissa (Kenya) in 2015. Al-Shabaab also infiltrated Puntland, the alleged home base of many of the Somali pirates.

\section{Summary}

The analysis of the genesis, evolution and strategies of the Islamist violent extremist groups in three parts of Africa (the borderland of Algeria and Mali; the borderland of Nigeria, Chad, Niger and Cameroon; and Eastern Africa) shows that religious agenda plays the role of a façade only. The most important reasons of the spread of terrorism are in connection with the political and economic conditions, feelings of relative deprivation, low level of trust in government authorities and the frustration of marginalised groups. It is not an accident that the birthplaces of these organisations are the areas inhabited by unemployed, often poorly educated, bigoted, young people - citizens of the failed and corrupted states, victims and veterans of civil wars. For these people access to a terrorist group is seen as a move up the social ladder and an improvement in standards of living. Where there is injustice, deprivation and desperation, violent extremist ideologies present themselves as a challenge to the status quo and a form of escape. ${ }^{35}$ The Salafist discourse and anti-Western sentiment are very useful tolls of social mobilisation. Similarly, despite their claims, the ultimate goals of all discussed terrorist organisations are solely political not religious. They seek to overthrow - or 'cure' - the existing political system and replace it with another (which often existed in the pre-colonial times).

Al-Shabaab, Boko Haram and AQIM in 2018 represent very different profiles than just a few years earlier. The organisations once perceived as exclusively 'Algerian', 'Nigerian', and 'Somali' have expanded their presence internationally. The structures of these violent extremist groups are fluent and flexible, and so are their affiliations - some announce their allegiance to Daesh and some to al-Qaeda, yet all adhere to the same extremist, fundamentalist and exclusive ideology to cover their political ambitions. Although their adaptive

33 DAskal, Jennifer C.: The Geography of the Battlefield: A Framework for Detention and Targeting Outside the 'Hot' Conflict Zone”. University of Pennsylvania Law Review, Vol. 161, No. 5, 2013, pp. 1197-1198.

34 Trumbull, George R.: On Piracy and the Afterlives of Failed States. Middle East Report, No. 256, 2010 , p. 15.

35 Journey to Extremism in Africa: Drivers, Incentives and the Tipping Point for Recruitment, [online], 2017, United Nations Development Programme. Source: Undp.org [20.02.2018.] 
nature and international character is a strength, rivalry in allegiances between particular war-lords and internal struggle for power may weaken the organisations, hopefully rendering the counter-terrorism efforts easier.

\section{REFERENCES}

Al-Ashmawy, Muhammad Said: Islam and the Political Order. The Council for Research in Values and Philosophy, Washington, D.C., 1994.

Al-Shabaab as a Transnational Security Threat. IGAD Security Sector Program (ISSP) and Sahan Foundation, Addis Ababa, 2016.

Angerbrandt, Henrik: Nigeria and the Lake Chad Region Beyond Boko Haram. Policy Note - the Nordic Africa Institute, No. 3, 2017.

Boko Haram: An Assessment of Strengths, Vulnerabilities, and Policy Options Report to the Strategic Multilayer Assessment Office, Department of Defense, and the Office of University Programs, Department of Homeland Security, [online], 2015, College Park: National Consortium for the Study of Terrorism and Responses to Terrorism - University of Maryland. Source: UMD.edu [22.08.2017.]

Chesney, Robert M.: Beyond the Battlefield, Beyond Al Qaeda: The Destabilizing Legal Architecture of Counterterrorism. Michigan Law Review, Vol. 112, No. 2, 2013, pp. 163-224.

Cliffe, Lionel - Love, Roy - Tronvoll, Kjetil: Conflict and Peace in the Horn of Africa. Review of African Political Economy, Vol. 36, No. 120, 2009, pp. 151-163. DOI: https://doi.org/10.1080/03056240903086485

Coleman, Katharina P.: Innovations in 'African solutions to African problems': the evolving practice of regional peacekeeping in sub-Saharan Africa. Journal of Modern African Studies, Vol. 49, No. 4, 2011, pp. 517-545. DOI: https://doi.org/10.1017/S0022278X11000462

Cronin, Audrey K.: The evolution of counter-terrorism: will tactics trump strategy? International Affairs, Vol. 86, No. 4, 2010, pp. 837-856. DOI: https://doi.org/10.1111/j.1468-2346.2010.00915.x

DASKaL, Jennifer C.: The Geography of the Battlefield: A Framework for Detention and Targeting Outside the 'Hot' Conflict Zone'. University of Pennsylvania Law Review, Vol. 161, No. 5, 2013, pp. 1165-1234.

DAvies, John: Understanding Terrorism in Africa. In: DAvies, John (ed.): Terrorism in Africa. The Evolving Front in the War on Terror. Lexington Books, Lanham, 2010, pp. 133-158.

De Monetsquiou, Alfred: Umma. Reporter na Bliskim Wschodzie. Terra Incognita, Warszawa, 2015.

Filiu, Jean-Pierre: The Local and Global Jihad of al-Qa ida in the Islamic Maghreb. Middle East Journal, Vol. 63, No. 2, 2009, pp. 213-226. DOI: https://doi.org/10.3751/63.2.12

Fowler, Robert: A Season in Hell. My 130 Days in the Sahara with Al Qaeda. Harper Collins, New York, 2011.

Harmon, Stephen A.: Terror and Insurgency in the Sahara-Sahel Region: Corruption, Contraband, Jihad and the Mali War of 2012-2013. Ashgate, Burlington-Farnham, 2014. DOI: https://doi.org/10.4324/9781315612096

Journey to Extremism in Africa: Drivers, Incentives and the Tipping Point for Recruitment, [online], 2017, United Nations Development Programme. Source: Undp.org [20.02.2018.]

Kendhammer, Brandon: The Sharia Controversy in Northern Nigeria and the Politics of Islamic Law in New and Uncertain Democracies. Comparative Politics, Vol. 45, No. 3, 2013, pp. 291-311. DOI: https://doi. org/10.5129/001041513805607829

Kepel, Gilles: Jihad: The Trail of Political Islam. Belknap Press, New York, 2002.

KLEIN, Adam: The End of Al Qaeda? Rethinking the Legal End of the War on Terror. Columbia Law Review, Vol. 110, No. 7, 2010, pp. 1865-1910.

LACHer, Wolfram: Organized Crime and Conflict in the Sahel-Sahara Region. Carnegie Endowment for International Peace, Washington, 2012.

LAUB, Zachary - Masters, Jonathan: Al-Qaeda in the Islamic Maghreb (AQIM), [online], 2015. Source: Council on Foreign Relations [31.08.2017.]

Littre, Peter D.: On the Somalia Dilemma: Adding Layers of Complexity to an Already Complex Emergency. African Studies Review, Vol. 55, No. 1, 2012, pp. 191-195. DOI: https://doi.org/10.1353/arw.2012.0018 
McGovern, Mike: Islamist Terrorism in the Sahel: Fact or Fiction?, [online], 2005. Source: International Crisis Group, Africa Report No. 92. [13.09.2017.]

Moland, Naomi A.: Can Multiculturalism Be Exported? Dilemmas of Diversity on Nigeria's Sesame Square. Comparative Education Review, Vol. 59, No. 1, 2015, pp. 1-23. DOI: https://doi.org/10.1086/679014

Murtada, Ahmad: "Boko Haram" in Nigeria: Its Beginnings, Principles and Actions in Nigeria. Bayero University, Kano, 2013.

Pham, J. Peter: Foreign Influences and Shifting Horizons: The Ongoing Evolution of al Qaeda in the Islamic Maghreb. Orbis, Vol. 55, No. 2, 2011, pp. 240-254. DOI: https://doi.org/10.1016/j.orbis.2011.01.005

Pringle, Robert: Democratization in Mali: Putting History to Work. U.S. Institute of Peace, Washington, 2006. Ruthven, Malise: Fundamentalism. The Search for Meaning. Oxford University Press, New York, 2004.

Schanzer, Jonathan: Al-Qaeda's Armies: Middle East Affiliate Groups and the Next Generation of Terror. Washington Institute for Near East Policy, Washington, D.C., 2004.

SEN, Amartya: Identity and Violence: The Illusion of Destiny. Norton and Company, New York, 2006.

Tномаs, Jakana: Rewarding Bad Behavior: How Governments Respond to Terrorism in Civil War. American Journal of Political Science, Vol. 58, No. 4, 2014, pp. 801-814. DOI: https://doi.org/10.1111/ajps.12113

Trumbull, George R.: On Piracy and the Afterlives of Failed States. Middle East Report, No. 256, 2010.

Uzodike, Ufo Okeke - Maiangwa, Benjamin: Boko Haram Terrorism in Nigeria: Casual Factors and Central Problematic. Africa Renaissance, Vol. 9, No. 1, 2012, pp. 91-118.

YAHAYA, Abubakar: Boko Haram and Islamic State of Iraq and Syria: The Nexus. Polac International Journal of Humanities and Security Studies, Vol. 2, No. 1, 2016, pp. 299-312. 